Marketing i Zarządzanie

nr 3 (53) 2018, s. 51-59

DOI: $10.18276 / \mathrm{miz} .2018 .53-05$

ISSN: 1509-0507 | http://wnus.edu.pl/pl/miz/

\title{
Joanna Dyczkowska
}

Politechnika Koszalińska

Wydział Nauk Ekonomicznych

e-mail: jdyczkowska@wp.pl

\section{Ocena operatora logistycznego przez pracownika i jego rozwój}

Kody JEL: M12, R49, L91

Słowa kluczowe: pracownik, operator logistyczny, klient wewnętrzny

Streszczenie. W artykule zaprezentowano przegląd literatury dotyczący istoty działań przedsiębiorstwa względem pracownika. Na przykładzie dwóch największych operatorów logistycznych wskazano, co wpływa na wybór pracownika i przedstawiono ocenę przedsiębiorstwa logistycznego jako pracodawcy. Celem artykułu jest prezentacja oceny operatora logistycznego jako pracodawcy i możliwości rozwoju kadry w przedsiębiorstwie logistycznym. Analizą objęto możliwość samorealizacji przez pracownika w sektorze logistycznym. W artykule wykorzystano analizę literatury i metodę pośrednich pomiarów sondażowych z zastosowaniem techniki kwestionariusza ankiety.

\section{Wprowadzenie}

Rozwój polskiej gospodarki w ostatnich latach spowodował, że przedsiębiorstwa potrzebują współpracy z profesjonalnymi dostawcami usług logistycznych w zakresie realizacji zleceń działań logistycznych od prostych usług logistycznych, jak dystrybucja lub magazynowanie, po zarządzanie łańcuchem dostaw. Doprowadziło to do wzrostu liczby operatorów logistycznych w celu spełnienia warunków wymagań logistycznych przedsiębiorstw. Aby usprawnić działanie, kompetencje i wydajność, niektórzy operatorzy logistyczni wykorzystują różne zautomatyzowane techniki i strategie zarządzania w celu poprawy wykonywa- 
nia zadań logistycznych, ale przede wszystkim ważny jest personel obsługujący klienta i kadra tzw. drugiej linii. Chociaż firmy logistyczne inwestują duże pieniądze i czas w realizację operacji logistycznych, kompetencje operacyjne i wydajność pracowników, często nie wykazują znacznej poprawy, ponieważ menedżerowie nie mogą tego zrobić systematycznie, a nie zawsze rozpoznają zadania logistyczne o niskiej wydajności lub brak doświadczenia u pracowników. Menedżerowie logistyki nie przyjmują systematycznego podejścia do określania wydajności w obsłudze procesów logistycznych. Dodatkowo dane logistyczne, jak czas przewozu przesyłki, mogą być dokładnie zebrane i zaimportowane do logistycznej bazy danych i w związku z tym można je stosować do oceny wydajności operatora. $\mathrm{W}$ takich okolicznościach menedżerowie mają trudności z ponownym wykorzystaniem i analizowaniem danych związanych $\mathrm{z}$ logistyką. Celem artykułu jest prezentacja oceny operatora logistycznego jako pracodawcy i możliwości rozwoju kadry w przedsiębiorstwie logistycznym. Analizą objęto możliwość samorealizacji przez pracownika w sektorze logistycznym. Metody zastosowane to analiza literatury i metoda pośrednich pomiarów sondażowych z zastosowaniem techniki kwestionariusza ankiety.

\section{Pracownik w przedsiębiorstwie logistycznym jako klient wewnętrzny}

Wykorzystanie firm świadczących usługi logistyczne rośnie w postępie geometrycznym na rynkach business-to-business, niewiele wiadomo jednak na temat tego, co pozwala niektórym z tych firm działać lepiej niż inne. Istota działań przedsiębiorstwa względem pracownika sprowadza się do rozpoznania jego potrzeb, przygotowania sytemu informacji wewnątrz organizacji, tworzenia odpowiedniego klimatu, warunków sprzyjających realizacji zadań, systemu motywacji oraz dostarczania satysfakcji zatrudnionych przez dotrzymywanie obietnic i powiązanie celów organizacji z indywidualnymi celami zatrudnionych (Biesaga-Słomczewska, Iwińska-Knop, 2012, s. 291). W przeszłości wiele publikacji wykorzystywało wywiady ekspertów w celu zidentyfikowania odpowiednich czynników oceny wydajności różnych branż. Sims i pozostali (Sims, Szilagyi Jr., Keller, 1976, s. 195-212) wykorzystywali wywiady wśród zatrudnionych w celu ustalenia, w jaki sposób pracownicy w branży medycznej i przemyśle wytwórczym zajmują się różnymi zadaniami, czy posiadają autonomię $\mathrm{w}$ wykonywanych zadaniach, utożsamiają się z nimi, uzyskują informacje zwrotne i mają szansę na przyjaźń w pracy. W celu zapewnienia kompleksowej struktury oceny wydajności Coleman i Borman (2000, s. 25-44) po raz pierwszy określili czynniki zachowań pracowników, bazując na poprzednich badaniach, i opracowali strukturę ewaluacyjną złożoną z interpersonalnych, organizacyjnych wymiarów zadań za pomocą kwestionariusza. Ponadto określili, jako klucz do kompleksowego zarządzania jakością (z ang. TQM), składniki, takie jak umiejętności rozwiązywania problemów przez pracowników jako 
czynnik oceny pracowników w realizacji zadań w określonym czasie. Kadra zarządzająca mogła zrozumieć wydajność implementacji TQM, oceniając wydajność pracowników za pomocą współczynników TQM (Deadrick, Gardnem, 1999, s. 225-241).

Przedsiębiorstwo opiera się na pracownikach, gdyż oni kreują pożądany obraz przedsiębiorstwa na zewnątrz (Mazurek-Łopacińska, 2002, s. 297-298). Pracownicy komunikują swoje zadowolenie na zewnątrz, kiedy firma buduje w środowisku pracy przyjazny klimat psychospołeczny, który służy większej integracji i przełamuje tendencje fluktuacyjne oraz ułatwia osiąganie pożądanych indywidualnych i zbiorowych zachowań pracowników (Schwał, Seidel, 1997, s. 11). Opierając się na opiniach przedsiębiorstw na temat zasobów, inni autorzy (Ellinger i in., 2008, s. 353-366) proponują badanie zwrócone na orientację i niektóre praktyki rozwoju pracowników (szkolenia, coaching i upodmiotowienie związane z obsługą) mające wpływ zarówno na pracowników, jak i ich wydajność organizacyjną. Wyniki ich sugerują, że po pierwsze orientacja rynkowa wpływa na wydajność organizacyjną i pracowników, po drugie coaching moderuje oba ogniwa, po trzecie szkolenie obsługi wpływa wyłącznie na wydajność pracownika i po czwarte - wzmocnienie nie zmienia żadnego $\mathrm{z}$ poprzednich czynników. W modelu piramidy wydajności (McNair, Lynch, Cross, 1990, s. 28-36) decydenci powinni określić czynniki oceny wydajności na podstawie struktury poziomów organizacji. Decydują o tym nie tylko poziom wykształcenia i doświadczenie zawodowe czy wydajność pracownika, ale także cechy pracy i warunki miejsca pracy (Kahwa, 2007, s. 515-523). Inwestycje w kapitał ludzki i oparcie działalności na kluczowych kompetencjach, jakie posiada personel, pozwala na zwiększenie wydajności i osiąganie wyznaczonych celów strategicznych oraz taktycznych i realizacji działań operacyjnych (Rosa, Jedliński, Chrąchol-Barczyk, 2017, s. 217).

\section{Wybór pracowników przez operatora logistycznego na przykładzie}

Oczekuje się, że komunikacja zorientowana na rynek będzie miała związek z wydajnością, a przedsiębiorstwa bazując na swoich zasobach, ugruntują swoją pozycję (Barney, 1991, s. 99-120). Według dostępnych badań, opierając się na zasobach, istniejących aktywach lub możliwościach rynkowych, możliwe jest kreowanie wartości firmy przez pracowników i budowanie przewagi nad konkurencją dzięki wyższej wydajności. Jeśli zasoby lub możliwości również stanowią wyzwanie dla konkurencji, to następuje naśladownictwo i alternatywne zasoby nie są dostępne, aby wykonać tę samą funkcję (Chi, 1994, s. 271-290). Opierając się na analizie zasobów, Hult i Ketchen (2001, s. 899-906) argumentowali, że orientacja rynkowa nie jest zasobem strategicznym, ale raczej niezbędnym składnikiem, choć najważniejsze dla strategii przedsiębiorstwa są zasoby kadrowe, które określają „przewagę pozycji”. Wcześniejsze badania 
potwierdzają, że orientacja rynkowa wpływa na różne wyniki przedsiębiorstwa, w tym behawioralne (Matsuno, Mentzer, Özsomer, 2002, s. 18-32) i finansowe miary wydajności organizacji (Han, Kim, Srivastava, 1998, s. 30-45), a także jakość obsługi klienta (Cole, Bacdayan, White, 1993, s. 68-81), utrzymanie klientów i wzrost sprzedaży (Narver, Slater, 1990, s. 20-35).

Pierwszy $\mathrm{z}$ analizowanych $\mathrm{w}$ artykule operatorów logistycznych - DB Schenker, stawia na specjalistów i menedżerów, którzy w swojej pracy nie obawiają się podważać status quo. Proponuje, by dołączyć do zespołu innowacyjnych ekspertów. W swojej globalnej sieci logistycznej oferuje wiele możliwości rozwoju w różnych obszarach firmy: od frachtu oceanicznego i transportu lotniczego oraz logistyki kontraktowej do działalności operacyjnej, IT, HR i innych. Poszukuje również osób do pracy na stanowisku zawodowego kuriera, gdzie DB Schenker oferuje stabilne zatrudnienie w firmach transportowych na stałe współpracujących z nim. Zakres obowiązków kuriera to odbiory, przewozy i dostawy przesyłek; kontakt ze stałymi klientami firmy Schenker sp. z o.o. według ustalonych tras. Czas pracy to poniedziałek-piątek (czasami sobota), $\mathrm{w}$ systemie dziennym. Wymagania to: wykształcenie minimum zawodowe, prawo jazdy kategorii $\mathrm{B}$, prawo jazdy kategorii $\mathrm{C}$ lub $\mathrm{C}+\mathrm{E}$ i kurs na przewóz rzeczy, uczciwość, zdolności komunikacyjne i kultura osobista. DB Schenker zapewnia stałe zatrudnienie na warunkach umowy o prace $\mathrm{w}$ firmach przewozowych obsługujących sieć logistyczną DB Schenker, ubezpieczenie zdrowotne kurierów od następstw NW na koszt Schenker sp. z o.o., szansę zdobycia doświadczenia w firmie będącej liderem na rynku, udział w atrakcyjnych i profesjonalnych szkoleniach, szkolenia wprowadzające, przydzielenie kurieraopiekuna na czas wdrażania, tani system służbowych połączeń telefonicznych, możliwość rozwoju zawodowego bezpośrednio w firmie Schenker oraz udział w projektach wolontariackich i zawodach sportowych (Stabilne..., 2018).

Drugi operator logistyczny - DP DHL - oferuje duże możliwości rozwoju i wyzwania w różnych działach oraz na różnych stanowiskach. Firma przywiązuje wagę do zapewnienia klientom usług i rozwiązań wysokiej jakości, a pracownikowi proponuje pracę dla przedsiębiorstwa o ogólnoświatowym zasięgu ukierunkowanego na obsługę klienta, jakość i zrównoważony rozwój oraz wykorzystującego siłę światowego handlu, z zamiarem łączenia ludzi i poprawiania jakości ich życia. Działa nie tylko z myślą o klientach, ale także o każdym członku grupy kapitałowej. Wspiera osoby zatrudnione w zdobywaniu wiedzy i rozwoju osobistym, pamiętając zarazem, że życie prywatne jest równie ważne i stymulujące jak praca. W ramach rozwijania możliwości zapewnia wiele okazji do poszerzania zakresu odpowiedzialności oraz zdobywania nowej wiedzy i doświadczenia. Oferuje również konkurencyjne wynagrodzenie, a także szkolenia z cyklu Certified - to inicjatywa obejmująca całą globalną grupę ukierunkowana na zaangażowanie pracowników i zmianę kulturową, wspierająca 
świadczenie najwyższej jakości usług. Dzięki szkoleniom można uzyskać wiedzę i umiejętności, pozwalające zaskakiwać klientów poziomem świadczonych usług. Firma oferuje również programy szkoleń z zakresu przywództwa prowadzone w ramach poszczególnych oddziałów, możliwości e-kształcenia oraz szkolenia funkcjonalne we wszystkich jednostkach biznesowych. Stanowią one odpowiedź na określone potrzeby rozwojowe. Dokształcanie obejmuje m.in. szkolenia z poszczególnych dziedzin wiedzy i umiejętności operacyjnych, szkolenia BHP, kursy językowe oraz z umiejętności miękkich. Dodatkowo oferowane są szkolenia $\mathrm{w}$ miejscu pracy, dzięki którym można poszerzyć umiejętności, wiedzę i zdobyć certyfikaty przydatne do lepszego reagowania na wyzwania napotykane w codziennej pracy. DHL daje szeroki wybór ofert pracy na całym świecie (Obszary kariery..., 2018).

\section{Ocena operatora logistycznego przez pracownika i rozwój zawodowy}

Przeprowadzone badania mają na celu analizę operatora logistycznego jako pracodawcy oraz możliwości rozwoju zawodowego. Ocena obejmuje grupę pracowników świadczących usługi logistyczne - kierowników średniego szczebla, obsługę klienta i kurierów - moderujących wpływ na relacje między rynkiem a przedsiębiorstwem i realizujących obsługę przesyłek. Badanie dotyczyło szkoleń związanych z obsługą, nieformalnego coachingu i wzmocnienia pozycji. Hipotezy analizowano, badając po pięciu pracowników z 10 dużych organizacji logistycznych. Wykorzystano metodę pomiarów sondażowych z zastosowaniem kwestionariusza ankiety. Badanie jakościowe (gdyż próba nie była reprezentatywna) miało na celu uzyskanie odpowiedzi, czy pracownik w przedsiębiorstwie logistycznym ma szanse i możliwości rozwoju oraz jakie czynniki mogą decydować o jego wyborze. Przyjęto trzy hipotezy:

H1. Pracownik operatora logistycznego jest pozytywnie kojarzony z obsługą klienta i pozytywnie ocenia firmę, w której pracuje.

H2. Pracownikom przedsiębiorstw logistycznych zapewnia się optymalne warunki i szkolenia w trakcie pracy.

H3. Wybór i rozwój pracownika zależy od wielu czynników, a brak właściwej kadry przyczynia się do zmian w ocenie pracownika.

Pracownicy w pierwszej kolejności oceniali atmosferę w miejscu pracy w skali 1-5, gdzie 1 to była zła, 2 - niezbyt dobra, 3 - średnia, 4 - dobra i 5 bardzo dobra. Średnia ocen to 4,44, czyli ocena powyżej dobrej. W drugiej kolejności oceniono samorealizację w przedsiębiorstwie (tab. 1), gdzie 1 oznaczało zdecydowanie nie, 2 - raczej nie, 3 - nie wiem, 4 - dobrze, 5 - bardzo dobrze. Okazało się, że pracownicy znają cele działalności firmy, w której pracują, a pracodawca wykorzystuje ich wiedzę, umiejętności i zdolności; mają też możliwość wpływania na swoją pracę poprzez współdecydowanie o zakresie obowiązków i podejmowanie decyzji co do kolejności obsługi klienta. Nie wszyscy 
pracownicy są związani z osobami, z którymi współpracują i nie zawsze wykazują chęć współpracy. Niestety w większości przypadków pomysły i inicjatywa pracownika nie są przychylnie przyjmowane i rzadko rozważane.

Tabela 1

Pracownik w przedsiębiorstwie logistycznym i jego samorealizacja

\begin{tabular}{|l|c|c|}
\hline \multicolumn{1}{|c|}{ Kryterium } & Liczba odpowiedzi & Średnia arytmetyczna \\
\hline Cele działalności przedsiębiorstwa & $100 \%$ & 4,8 \\
\hline Możliwość wpływania na swoją pracę & $98 \%$ & 4,3 \\
\hline $\begin{array}{l}\text { Wykorzystanie wiedzy, umiejętności } \\
\text { i zdolności }\end{array}$ & $96 \%$ & 4,4 \\
\hline $\begin{array}{l}\text { Pomysły i inicjatywa są przychylnie } \\
\text { przyjmowane i rozważane }\end{array}$ & $92 \%$ & 2,8 \\
\hline $\begin{array}{l}\text { Związek z grupą, w której pracuje i chęć } \\
\text { współpracy w ramach danej grupy }\end{array}$ & $98 \%$ & 3,8 \\
\hline
\end{tabular}

Źródło: opracowano na podstawie przeprowadzonych badań.

W tabeli 2 ujęto odpowiedzi badanych w zakresie ich oceny możliwości i szans rozwoju pracowników. Użyto skali: 1 - w ogóle nie mam, 2 - raczej nie mam, 3 - nie wiem, 4 - w zasadzie mam, 5 - mam w bardzo dużym stopniu.

Tabela 2

Szanse i możliwości rozwoju w przedsiębiorstwie logistycznym

\begin{tabular}{|l|c|c|}
\hline \multicolumn{1}{|c|}{ Kryterium } & Liczba odpowiedzi & Średnia arytmetyczna \\
\hline $\begin{array}{l}\text { Rozwój osobisty (doskonalenie charakte- } \\
\text { ru, zachowań, pozytywnych wartości) }\end{array}$ & $100 \%$ & 2,1 \\
\hline $\begin{array}{l}\text { Zdobywanie nowej wiedzy i doskonale- } \\
\text { nie umiejętności }\end{array}$ & $100 \%$ & 4,5 \\
\hline Wykonywanie różnorodnych zadań & $100 \%$ & 4,7 \\
\hline $\begin{array}{l}\text { Awans „poziomy” - przyjęcie szerszej } \\
\text { odpowiedzialności i nowych zadań }\end{array}$ & $92 \%$ & 3,8 \\
\hline Awans na wyższe stanowisko & $92 \%$ & 1,5 \\
\hline
\end{tabular}

Źródło: opracowano na podstawie przeprowadzonych badań.

Okazało się, że badani pracownicy nie mają możliwości awansu na wyższe stanowisko, a w większym stopniu przedsiębiorstwo pozwala im na tzw. awans poziomy przez przyjęcie szerszej odpowiedzialności i nowych zadań. Badani negatywnie ocenili swój rozwój osobisty, choć w bardzo dużym stopniu zdobywają nową wiedzę, doskonalą swoje umiejętności i wykonują różnorodne zadania.

Dodatkowo zapytano pracowników, ile dni szkoleń odbyli w ciągu ostatnich 12 miesięcy i okazało się, że było to:

- średnio dla kadry zarządzającej - 145 godzin,

- obsługa klienta $-76,5$ godziny,

- kurierzy -18 godzin. 
Najsłabiej szkoloną grupą mającą kontakt z klientem są kurierzy - tylko na początku rozpoczęcia pracy i przy zmianach procedur, najwięcej szkoleń przeznaczano dla kadry zarządzającej średniego szczebla - średnio na miesiąc 12 godzin. Spedytorzy i pracownicy biura obsługi klienta średnio przeznaczają jeden dzień w miesiącu na szkolenia.

\section{Podsumowanie}

Operatorzy logistyczni poszukują pracowników na praktycznie wszystkie stanowiska - od magazyniera, kuriera, pracowników obsługi klienta po kadrę zarządzającą. Liczba kandydatów jest ograniczona, gdyż specyfika organizacji przewozów jest skomplikowana i wymaga wiedzy z wielu dziedzin. Dodatkowo często poszukiwane są osoby ze znajomością negocjacji, komunikacji i języków obcych. Kandydaci wybierają tych pracodawców, którzy kierują się podobnymi wartościami oraz wyróżniają się w stosunku do innych firm na rynku, stąd wybór ich pada na globalnych operatorów logistycznych, którzy nie tylko proponują płacowe systemy motywacyjne, stabilną pracę, ale całe pakiety socjalne.

Pracownicy operatorów logistycznych są pozytywnie kojarzeni z obsługą klienta i pozytywnie oceniają swoich pracodawców, ale mimo takiej oferty nisko oceniają możliwość awansu na wyższe stanowisko i rozwój osobisty. Cenią możliwość zdobywania nowej wiedzy i doskonalenia umiejętności oraz wykonywania różnorodnych zadań. W niektórych organizacjach $\mathrm{z}$ branży logistycznej istnieje awans ,poziomy” przez przyjęcie szerszej odpowiedzialności i nowych zadań. Kadra operatorów logistycznych ceni atmosferę pracy, zna ogólne cele działalności firmy oraz ma możliwość wpływania na swoją pracę. Niestety nie zawsze są wykorzystywane pomysły i inicjatywy pracowników. W niewielkim stopniu szkoleni są kurierzy, którzy mają pierwszy kontakt z klientem, zaś w większym - pracownicy biura obsługi klienta i kadra zarządzająca. Pracodawca, jakim jest operator logistyczny, umożliwia rozwój zawodowy przez szkolenia, ale mimo tego rozwoju nie umożliwia awansu. Skala problemu braków kadrowych w logistyce jest bardzo poważna, a niedobór pracowników na różnych szczeblach w organizacji może się pogłębiać przy obecnym rozwoju gospodarki. Pracodawcy w branży logistyki kontraktowej muszą zatem modyfikować ofertę zatrudnienia dla obecnych i nowych pracowników.

\section{Bibliografia}

Barney, J. (1991). Firm resources and sustained competitive advantage. Journal of Management Studies, 17 (1), 99-120.

Biesaga-Słomczewska, E.J., Iwińska-Knop, K. (2012). Relacje wewnętrzne w kreowaniu lojalności pracowników. Zeszyty Naukowe Uniwersytetu Szczecińskiego, 712, Problemy Zarzadzania, Finansów i Marketingu, 26, 289-299.

Chi, T. (1994). Trading in strategic resources: Necessary conditions, transaction cost problems, and choice of exchange structure. Strategic Management Journal, 15 (4), 271-290. 
Cole, R.E., Bacdayan, P., White, J.B. (1993). Quality, participation and competitiveness. California Management Review, 35 (3), 68-81.

Coleman, V.I., Borman, W.C. (2000). Investigating the underlying structure of the citizenship performance domain. Human Resource Management Review, 10 (1), 25-44.

Deadrick, D.L., Gardner, D.G. (1999). Performance distributions: measuring employee performance using total quality management principles. Journal of Quality Management, 4 (2), 225-241.

Ellinger, A.E., Ketchen Jr., D.J., Hult, G.T., Elmadag, A.B., Richey Jr., R.G. (2008). Market orientation, employee development practices, and performance in logistics service provider firms. Industrial Marketing Management, 37 (4), 353-366.

Han, J.K., Kim, N., Srivastava, R.K. (1998). Market orientation and organizational performance: Is innovation a missing link? Journal of Marketing Research, 62 (4), 30-45.

Hult, G.T., Ketchen Jr., D.J (2001). Does market orientation matter? A test of the relationship between positional advantage and performance. Strategic Management Journal, 22 (9), 899-906.

Kahya, E. (2007). The effects of job characteristics and working conditions on job performance. International Journal of Industrial Ergonomics, 37 (6), 515-523.

Matsuno, K., Mentzer, J.T., Özsomer, A. (2002). The effects of entrepreneurial proclivity and market orientation on business performance. Journal of Marketing, 66 (3), 18-32.

Mazurek-Łopacińska, K. (2002). Orientacja na klienta w przedsiębiorstwie. Warszawa: PWE.

McNair, C.J., Lynch, R.L., Cross, K.F. (1990). Do financial and non-financial measures of performance have to agree? Management Accounting, 72 (5), 28-36.

Narver, J.C., Slater, S.F. (1990). The effect of a market orientation on business profitability. Journal of Marketing, 54, 20-35.

Obszary kariery w DHL (30.06.2018). DHL. Pobrano z: https://www.logistics.dhl/pl-pl/home/ praca/pracujacy-tutaj/obszary-kariery.html.

Rosa, G., Jedliński, M., Chrąchol-Barczyk, U. (2017). Marketing usług logistycznych. Warszawa: C.H. Beck.

Schwał, K., Seidel, K.G. (1997). Marketing kadrowy. Warszawa: C.H. Beck.

Sims, H.P., Szilagyi Jr., A.D., Keller, R.T. (1976). The measurement of job characteristics. Academy of Management Journal, 19 (2), 195-212.

Stabilne zatrudnienie w firmach dostawców DB Schenker (30.06.2018). DB Schenker. Pobrano z: https://www.dbschenker.com/pl-pl/kariery/przewo\%C5\%BAnicy-i-kurierzy/zosta\%C5\%84 -kurierem-db-schenker.

\section{Evaluation of the Logistic Operator by the Employee and his Development}

Keywords: employee, logistics operator, internal client

Summary. The paper presents the review of the literature concerning the essence of the company's activities in relation to the employee, described on the example of the two of the largest logistics operators, which affects the choice of the employee. The assessment of logistics operator as an employer is also presented. The objective of the paper is to present an assessment of a logistics operator as an employer and opportunities for the development of staff in a logistics company. The analysis included the possibility of self-fulfillment by an employee in the logistics sector. The methods used are literature analysis method and indirect measurement survey using the questionnaire technique.

Translated by Joanna Dyczkowska 


\section{Cytowanie}

Dyczkowska, J. (2018). Ocena operatora logistycznego przez pracownika i jego rozwój. Marketing $i$ Zarzadzanie, 3 (53), 51-59. DOI: 10.18276/miz.2018.53-05. 